\title{
Anti-inflammatory effect of barley leaf ethanol extract in LPS-stimulated RAW264.7 macrophage
}

\author{
Mee-Kyung Kim ${ }^{1}$, Dae-Yong $\mathrm{Kim}^{2 *}$ \\ ${ }^{1}$ Department of Cosmetic Science and Technology, Seowon University, Cheongju 28674, Korea \\ ${ }^{2}$ Department of Pharmaceutical Science and Engineering, Seowon University, Cheongju 28674, Korea
}

LPS로 자극한 RAW264.7 대식세포에서 보리순 에탄올 추출물의 항염증 효과

\author{
김미경 ${ }^{1} \cdot$ 김대용 $^{2 *}$ \\ ${ }^{1}$ 서원대학교 화장품과학과, ${ }^{2}$ 서원대학교 제약공학과
}

\begin{abstract}
This study investigated the anti-inflammatory activity of barley leaf extract in lipopolysaccharide (LPS)-stimulated RAW264.7 cells and hairless mice. Pre-treatment with barley leaf extract significantly inhibited the protein expression of inducible nitric oxide synthase (iNOS) and cyclooxygenase-II (COX-II) in a dose-dependent manner in LPS-stimulated RAW264.7 cells. Barley leaf extract also significantly inhibited the secretion of inflammatory cytokines, such as tumor necrosis factor- $a$ (TNF- $a$ ), interleukin-1 $\beta$ (IL-1 $\beta$ ), and interleukin-6 (IL-6). Moreover, phosphorylation of mitogen-activated protein kinases (MAPKs) and nuclear translocation of nuclear factor-kappa B (NF- $\kappa B$ ) were strongly suppressed by barley leaf extract in LPS-stimulated cells. In hairless mice, barley extract significantly decreased the pathological phenotypes of contact dermatitis, such as erythema, edema, and scabs. These results indicate that barley leaf extract has an anti-inflammatory effect and therefore a possible role in the treatment of inflammatory diseases or in functional cosmetics.
\end{abstract}

Key words : barley leaf, anti-inflammatory activity, inflammatory cytokine, MAPK, contact dermatitis

\section{서 론}

염증(inflammation)은 감염, 화학물질, 면역 반응과 같은 다양한 자극에 의하여 매개될 수 있는 인체 조직의 손상에 대한 자연적인 생물학적 반응이다(1). 이런 염증반응에서 중요한 역할을 수행하고 있는 세포 중에 하나가 대식세포 (macrophage)이다. 대식세포는 그들의 식세포 작용 (phagocytosis), 세포 독성(cytotoxicity), 세포살해능력을 활 용하여 숙주의 방어 기작에 중요한 역할을 수행한다(2).

Lipopolysaccharide(LPS)는 그람음성균의 세포벽에서 유 도된 화합물로 염증성 사이토카인의 강력한 유도제로 알려

*Corresponding author. E-mail : dykim@seowon.ac.kr Phone : 82-43-299-8412, Fax : 82-43-299-8740

Received 13 August 2015; Revised 5 October 2015; Accepted 8 October 2015.

Copyright (c) The Korean Society of Food Preservation. All rights reserved.
져 있다. LPS에 의하여 nitric oxide(NO), tumor necrosis factor- $a(\mathrm{TNF}-\mathrm{a})$, interleukin(IL), prostaglandin(PG), leukotrience 와 같은 염증성 매개체들이 생성이 증가된다. LPS로 활성 화시킨 RAW264.7 대식세포는 항염증 소재를 탐색하는 방 법으로 널리 사용되고 있다. RAW264.7 세포에 LPS로 자극

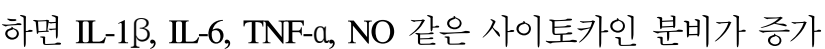
한다(3). NO는 nitric oxide synthase(NOS)에 의해 L-arginine 으로부터 생성된다. NOS는 혈관긴장도, 신경전달, 미생물 제거, 항상성 메커니즘 등을 조절하는 중요한 역할을 수행 한다. Inducible NOS(iNOS)는 스트레스나 IL-1ß, IL-6, TNF- $\alpha$ 와 같은 염증성 사이토카인에 의해 발현된다. 이런 사이토카인들은 대식세포를 활성화시키고 급성 및 만성 염증반응을 일으키는 매개체로 작용한다 $(4,5)$. 그러므로 이 런 염증성 사이토카인과 여러 매개체를 조절하는 것은 다양 한 염증관련 질환의 치료제 개발에 있어서 중요한 요소이 다. 또한 항염증 소재 개발을 위한 중요한 타겟이 될 수 있다. 
최근에는 항염 소재를 천연물에서 찾고자 하는 연구들이 활발하게 진행되고 있다. 블루베리 잎 추출물에서 항산화 및 항염 효과를 확인하였고(6) 질경이 종자 추출물에서는 항산화 활성에 관한 연구(7)가 진행되었으며 백량금 열매추 출물에서는 항산화 및 항염작용에 관한 연구(8)가 진행되었 다. 또한 녹차 초임계 추출물에서는 피부 염증 유발균에 대한 항균활성 및 항산화 효과에 대한 연구(9)가 진행되었 다. 이처럼 부작용이 적고 유용한 생리활성 물질을 가진 천연 소재는 의약품, 식품 및 화장품 소재에 이르기까지 그 활용가치가 매우 높다.

보리는 세계 4대 작물 중 하나이다. 우리나라의 경우, 오곡(쌀, 보리, 조, 콩, 기장) 중 하나이며 쌀 다음가는 주식 곡물이다. 월년생 초본으로서 식량작물로는 가장 오래된 작물 중의 하나이다. 여러 연구에 의하면 보리잎에는 다양 한 생리활성 물질이 풍부하게 들어있다고 보고되었다. 특 히 보리잎 추출물에는 강력한 항산화제인 SOD, 비타민 C, 비타민 E, $\beta$-carotene이 다량 함유되어 있다(10). 그러나 보 리순에 대한 체계적인 효능 검증은 매우 미약한 실정이다. 따라서 본 연구에서는 보리순 추출물을 이용하여 항염증 효과를 검증하여 천연물질의 기능성 소재로서의 적용 가능 성을 확보하여 여러 분야에 적용 가능한 기초자료를 제공하 고자 한다.

\section{재료 및 방법}

\section{보리순 추출물의 제조}

본 실험에서 사용한 보리순은 전라남도 보성에서 구입하 여 $4{ }^{\circ} \mathrm{C}$ 에서 저온 저장하여 이용하였다. 에탄올 추출물은 시료 중량의 10 배의 $70 \%$ 에탄올을 첨가하여 실온에서 24 시 간 교반하여 추출하고 추출후 상층액과 침전물을 분리하였 다. 동일한 방법으로 3 회 반복하여 추출하였다. 추출액은 여과지(Whatman No. 2, Sigma-Aldrich, MO, USA)를 이용 하여 여과한 후 감압농축기(N-100, EYELA, Tokyo, Japan) 로 농축하여 동결건조하였다. 그 후 냉동실에서 보관하면 서 실험에 사용하였다.

\section{세포 배양}

마우스 대식세포 RAW264.7는 10\% heat-inactivated FBS(HyClone, PA, USA), $100 \mathrm{U} / \mathrm{mL}$ penicillin/streptomycin (HyClone, PA, USA)을 함유한 DMEM(HyClone, PA, USA) 배양액에서 $37^{\circ} \mathrm{C}, 5 \% \mathrm{CO}_{2}$ 조건으로 배양기에서 배양하였 다.

\section{세포 독성 측정}

보리순 에탄올 추출물의 대식세포에 대한 세포 독성은 Berridge 등(11)의 연구를 참고하여 CellTiter 96® AQueous
One Solution Cell Proliferation assay kit(promega, WI, USA) 를 사용하여 측정하였다. RAW264.7 세포를 $10 \% \mathrm{FBS}$ 를 포함한 DMEM에 현탁시킨 후 96 well plate(Corning, NY, USA)에 $5 \times 10^{4}$ cells $/ \mathrm{mL}$ 의 세포를 $100 \mathrm{~mL}$ 씩 분주하여 $37^{\circ} \mathrm{C}$ $5 \% \mathrm{CO}_{2}$ incubator에서 24시간 배양한 후 보리순 에탄올 추출물을 농도별 $(0,5,10,50,100,500,1000 \mu \mathrm{g} / \mathrm{mL})$ 로 처리 한 후 24시간동안 배양하였다. 배양액을 제거 한 후 kit manual에 따라 실험을 진행하여 $540 \mathrm{~nm}$ 에서 흡광도를 측정 하였다.

\section{염증성 사이토카인 발현 측정}

염증성 사이토카인의 측정은 효소면역정량법(enzyme linked immunosorbent assay, ELISA) 방법을 이용하였다 (12). 96-well plate에 RAW264.7 세포를 $4 \times 10^{5}$ cells/well로 현탁하고, 다양한 농도의 보리순 에탄올 추출물 $(50,100$ $\mathrm{\mu g} / \mathrm{mL})$ 을 전처리 하고 2시간 뒤에 $\mathrm{LPS}(1 \mu \mathrm{g} / \mathrm{mL})$ 로 자극하 여 24시간 배양하였다. 배양이 끝난 세포들을 모아 원심분 리하여 상층액만을 수집하여 TNF-a, IL-1ß, IL-6를 ELISA $\mathrm{kit}(\mathrm{R} \& \mathrm{D}$ Systems, MN, USA)를 이용하여 측정하였다.

\section{Nitric oxide(NO) 함량 측정}

RAW264.7 세포를 10\% FBS가 포함된 DMEM 배지에 $1 \times 10^{5}$ cells $/ \mathrm{mL}$ 의 세포수로 96 well plate(Corning, NY, USA) 에 분주한 다음, 보리순 에탄올 추출물 $50,100 \mathrm{\mu g} / \mathrm{mL}$ 으로 세포에 처리하여 2시간 동안 배양한 후 자극제 $\operatorname{LPS}(1 \mu$ $\mathrm{g} / \mathrm{mL}$ )를 처리하고 배양하였다. 24시간 후 세포배양 상등액 $100 \mu \mathrm{L}$ 과 Griess 시약( $1 \%$ sulfanilamide, $0.1 \%$ naphthylethylendiamine in $2.5 \%$ phosphoric acid) $100 \mu \mathrm{L}$ 를 혼합하여 96 well plate에서 10 분간 반응시킨 다음, $540 \mathrm{~nm}$ 에서 흡광도를 측정하였다.

\section{염증관련 단백질 발현 측정}

$\mathrm{RAW} 264.7$ 세포를 $10 \% \mathrm{FBS}$ 를 포함한 DMEM에 현탁시 킨 후 6 well plate(Corning, NY, USA)에 $4 \times 10^{5}$ cells $/ \mathrm{mL}$ 의 세포수가 되도록 $3 \mathrm{ml}$ 씩 분주하여 $37^{\circ} \mathrm{C} 5 \% \mathrm{CO}_{2}$ incubator에 서 24시간 배양하였다. 새로운 DMEM배지로 교환한 후 보리순 에탄올 추출물 $50,100 \mu \mathrm{g} / \mathrm{mL}$ 으로 세포에 처리하여 2시간 동안 배양한 후 자극제 LPS를 처리하고 배양하였다. 24 시간 후 단백질 발현을 측정하기 위하여 배지를 제거하 고 cold PBS로 세척한 후 cell lysates는 lysis buffer $(10 \mathrm{mM}$ pH 7.4 Tris-HCl, 5 mM NaF, 1 mM Na3 $V_{4}, 1$ mM EDTA $\mathrm{abd} 1 \mathrm{mM} \mathrm{EGTA}$ )를 첨가하여 단백질을 추출하였다. 단백 질을 정량하여, $10 \% \mathrm{SDS}-\mathrm{PAGE}$ 에 전기영동 한 후, membrane으로 transfer하여 5\% skim milk에 1시간동안 blocking하였다. COX-II, iNOS, MAPKs 및 phospho-IKBa의 단백질 발현은 $\mathrm{ECL}($ Amersham, PA, USA)을 이용하여 확인 하였다(12). 


\section{핵단백질 추출}

$\mathrm{NF}-\mathrm{kB}$ 의 활성화 정도를 분석하기 위해 보리순 에탄올 추출물 $(50,100 \mathrm{\mu g} / \mathrm{mL})$ 을 처리한 RAW264.7 세포로부터 핵단백질을 분리하였다. 보리순 추출물로 처리된 세포 $\left(2 \times 10^{6}\right.$ cells/dish)를 PBS로 세척하여 회수하고, $180 \mu \mathrm{L}$ 의 hypotonic buffer $(10 \mathrm{mM}$ Tris-HCl, $10 \mathrm{mM} \mathrm{NaCl}, 3 \mathrm{mM}$ $\mathrm{MgCl}_{2}, 0.02 \% \mathrm{NaN}_{3}, 0.5 \mathrm{mM}$ DTT, $1 \mathrm{mM}$ PMSF, $\mathrm{pH}$ 7.4)를 넣고, $20 \mu \mathrm{L}$ 의 $5 \%$ nonidet NP-40을 첨가하여 5 분 동안 반응 시켰다. 이후 원심분리 $\left(1,800 \times \mathrm{g}, 4^{\circ} \mathrm{C}, 5\right.$ 분 $)$ 한 후 상층액을 세포질 추출물로 이용하였다. 침전물은 hypotonic buffer로 한 번 세척하고, hypertonic buffer(20 mM 4-(2-hydroxyethyl)1-piperazineethanesulfonic acid, 25\% glycerol, $420 \mathrm{mM}$ $\mathrm{NaCl}, 1.5 \mathrm{mM} \mathrm{MgCl} 2,0.2 \mathrm{mM}$ ethylenediaminetetraacetic acid, $0.02 \% \mathrm{NaN}_{3}, 0.5 \mathrm{mM} \mathrm{DTT}, 1 \mathrm{mM}$ PMSF, $\mathrm{pH}$ 7.4)를 넣고 1 시간 동안 얼음 위에 방치시킨 다음 원심분리 $\left(13,000 \times \mathrm{g}, 4^{\circ} \mathrm{C}, 10\right.$ 분 $)$ 하여 상층액을 회수하여 핵 단백질을 분리하여 실험에 이용하였다.

\section{Oxazolone를 이용한 접촉성 피부염 모델}

만성 접촉성 피부염 모델을 위해 oxazolone으로 감작시 킨 뒤 반복적으로 피부에 도포하여 접촉성 피부염을 유도한 뒤 병변 부위를 관찰함으로써 보리순 에탄올 추출물의 만성 접촉성 피부염 저해효과를 확인하였다(13). 실험은 hairless 마우스의 등 부위에 에탄올 $100 \mu \mathrm{L}$ 의 $5 \%$ oxazolone을 잘 도포하여 감작시켰다. 그리고 7일후 추출물을 잘 도포한 다음 30 분 후에 다시 oxazolone을 $5 \%$ 로 조제하여 도포하여 접촉성 피부염을 유발시켰다. 2 일 간격으로 9 회 반복하여 피부염을 유발시키고 병변 부위를 관찰하였다(Fig. 1). 보리 순 추출물은 에탄올 $200 \mu \mathrm{L}$ 에 $100 \mu \mathrm{g} / \mathrm{mL}$ 농도로 도포하였 다. 음성 대조군은 ethanol만을 도포하였고 양성 대조군은 oxazolone에 보리순 추출물 대신 ethanol만을 도포하였다.

\section{통계처리}

실험 결과의 통계처리는 SPSS 프로그램(10.0, SPSS Inc., Chicago, IL, USA)을 사용하였으며, 유의차 검증은 one-way ANOVA test를 이용하여 분석하였다.

\section{결과 및 고찰}

\section{보리순 추출물에 대한 RAW264.7 세포 독성 측정}

대식세포는 염증 반응에 관여하는 주요한 세포로 알려져 있으며 여러 가지 자극원 또는 다른 세포들이 분비하는 사이토카인에 의해서 활성화되는데 이런 대식세포에 의해 서 부종, 열, 통증 등의 염증 반응이 유발되고 염증 부위로 다른 면역세포들을 이동시킨다(14). 그러므로 본 연구에서 는 염증 반응에 중요한 역할을 수행하는 대식세포에 대한 보리순 에탄올 추출물의 효과를 확인하기 위하여 먼저 대식 세포에 대한 세포 독성을 확인하였다. 보리순 에탄올 추출 물 $5,10,50,100,500,1000 \mu \mathrm{g} / \mathrm{mL}$ 의 농도를 첨가하여 proliferation kit를 이용하여 세포 생존율을 측정하여 Fig. 2 에 나타내었다. 실험 결과를 보면, 보리순 에탄올 추출물 $1000 \mathrm{\mu g} / \mathrm{mL}$ 에서 약간의 독성이 관찰되었으나 나머지 농도 에서는 세포 독성이나 성장 저해 효과는 보이지 않았다. 보리순 에탄올 추출물은 고농도를 제외하면 세포 독성을 보이지 않으므로 기능성 소재로서의 적용 가능성을 가질 것으로 보인다.

보리순 추출물이 NO 생성과 COX-II와 iNOS 발현에 미 치는 영향

염증의 초기 반응은 주로 COX-II와 iNOS와 이들에 의한 친염증성 매개물들에 의해 유도되며 여기에는 PGE2와 $\mathrm{NO}$ 등이 있다(15). COX-II는 PG를 통하여 상피 세포의 재생,

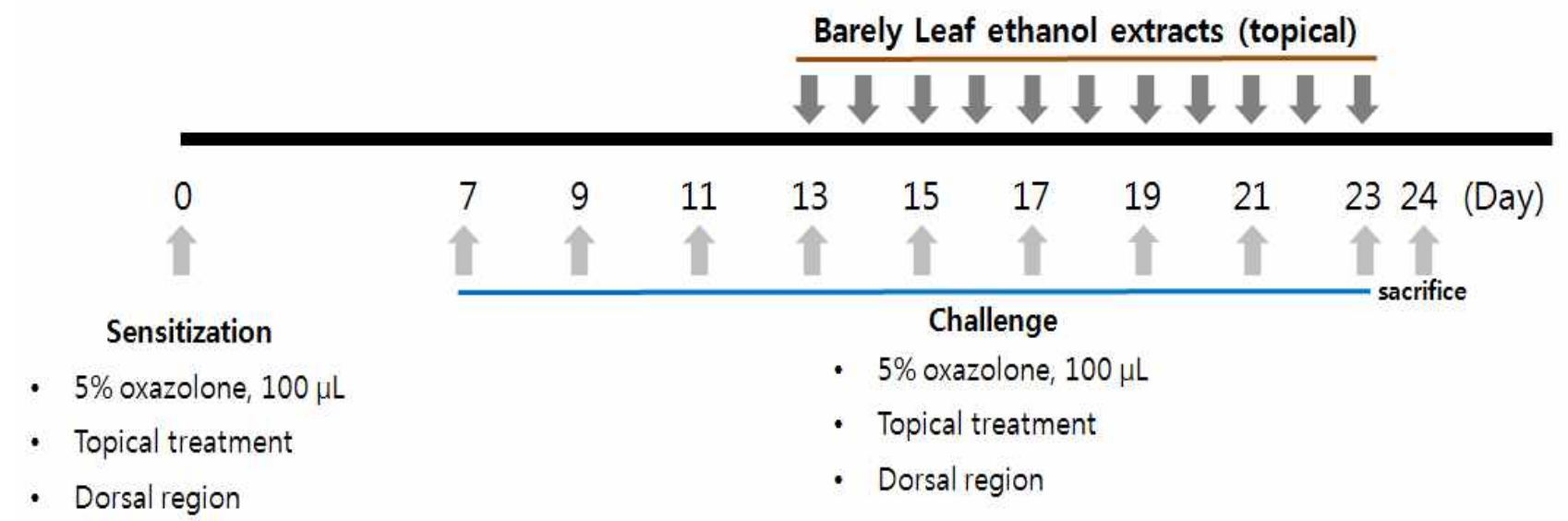

Fig. 1. Oxazolone challenges and topical administration of barley leaf ethanol extract.

Mice were sensitized with oxazolone $(5 \%, 100 \mu \mathrm{L})$ or EtOH $(100 \mu \mathrm{L})$ to dorsal skin. After seven days, each mouse was sensitized with oxazolone to the same skin site. Hairless mice received nine epicutaneous applications of $5 \%$ oxazolone after treatment of $100 \mu \mathrm{g} / \mathrm{mL}$ barley leaf ethanol extracts on alternate days on the dorsal skin. Twenty-four hours after the last applications of 5\% oxazolone, each mouse was observed. 


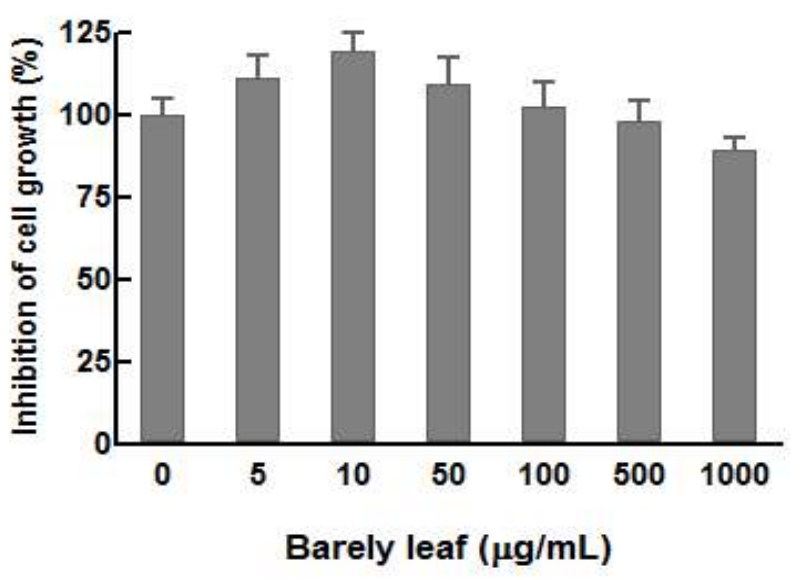

Fig. 2. Effect of barley leaf ethanol extract on cell viability of RAW264.7 cells.

RAW264. cells pretreated with various concentrations of barley leaf ethanol extract for $24 \mathrm{~h}$, cell viability analyzed by proliferation assay kit.

혈관 생성 등을 자극하며, 종양 형성에도 참여하는 것으로 보고되고 있다. 또한 류마티스 관절염 같은 만성 염증 질환 과 대장, 두경부, 폐, 방광, 전립선, 위 등 인체에 발생한 악성 종양에서 COX-II가 발현되어 여러 질병의 표적이 되 었으며, COX-II 억제제를 이용한 치료법 개발에 관한 연구 결과들이 보고되고 있다(16). NO 생성은 대부분 iNOS에 의한 생성이 많으며 생성된 $\mathrm{NO}$ 는 박테리아를 제거하는 역할을 하지만 과도하게 생성될 경우 염증을 일으켜 조직 손상, 유전자 변이, 신경 손상을 유발한다. iNOS는 외부자 극에 반응하여 생체를 방어하려는 목적으로 단시간에 과량 의 $\mathrm{NO}$ 를 생성하게 된다(17). 또한 $\mathrm{iNOS}$ 는 LPS 등과 같은 활성물질을 처리했을 경우에도 증가된다고 알려져 있다. 따라서 iNOS의 발현양상에 대한 연구가 활발히 진행 중이 다(18). 그래서 본 연구에서는 LPS 유도된 RAW 264.7 대식
세포에 보리순 에탄올 추출물을 처리하여 염증성 매개물들 의 발현을 관찰하였다. 실험은 LPS자극과 보리순 에탄올 추출물을 처리한 후, 세포배양 상등액에서 NO 함량을 측정 하였고 세포질에서 단백질을 분리하여 western blot 방법을 이용하여 COX-II와 iNOS의 단백질 발현양을 측정하였다. 그 결과, LPS를 대식세포에 처리하므로써 NO 생성이 증가 하였고 COX-II와 iNOS의 단백질 발현이 현저히 증가되는 것을 확인하였다. 그리고 증가된 $\mathrm{NO}$ 함량과 단백질 발현이 보리순 에탄올 추출물을 처리했을 때 농도의존적으로 감소 되었다(Fig. 3).

보리순 추출물이 염증성 사이토카인 생성에 미치는 영향

신체에 염증 반응이 개시되기 위해서는 많은 인자들이 관여하게 된다. 이때 다양한 염증 매개물이 관여하게 되는 데 그 중에서 염증성 사이토카인이 참여하게 된다. 이러한 세포 내 다양한 염증조절인자들은 TNF-a, IL-1 $\beta, \mathrm{IL}-6, \mathrm{IL}-8$ 등과 같은 proinflammatory cytokines, $\mathrm{PG}$, 활성산소 등 다양 한 매개물질이 관여한다 $(19,20)$. 특히 대식세포에서 LPS와 같은 자극에 의하여 염증 반응에 관계된 전사 인자가 활성 화되고 그 결과로 $\mathrm{iNOS}, \mathrm{COX}-\mathrm{II}$ 를 발현시켜 NO와 PGE2를 생성하여 염증을 일으킨다(21). 따라서 보리순 추출물이 염증성 사이토카인의 생성에 미치는 영향을 살펴보기 위하 여 RAW264.7 세포에 LPS를 처리한 후, 추출물을 농도별로 처리하여 ELISA 방법을 이용하여 측정하였다. 그 결과 모 든 사이토카인이 보리순 에탄올 추출물에 의하여 생성이 억제됨을 확인하였다(Fig. 4). TNF- $a$ 의 경우 보리순 추출물 $50,100 \mu \mathrm{g} / \mathrm{mL}$ 에서 각각 $81.8 \%, 84.9 \%$ 의 억제율을 나타내 었고 농도간의 차이는 크게 나지 않았다. IL- $\beta$ 는 각 농도별 로 $36 \%, 57 \%$ 의 억제율로 농도의존적인 경향을 나타내었 다. IL-6는 각 농도별로 $30.6 \%, 51.8 \%$ 의 억제율로 농도의존 적인 경향을 나타내었다.

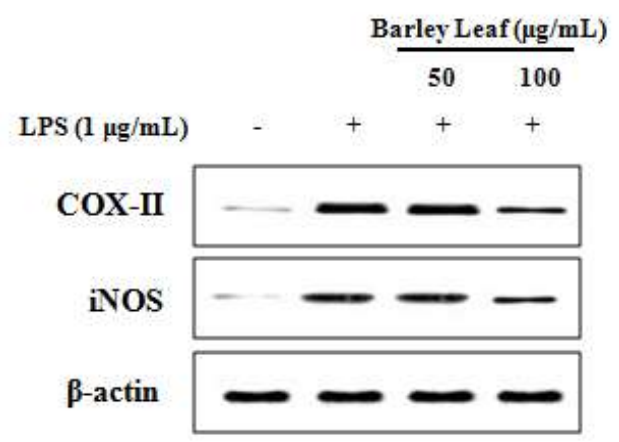

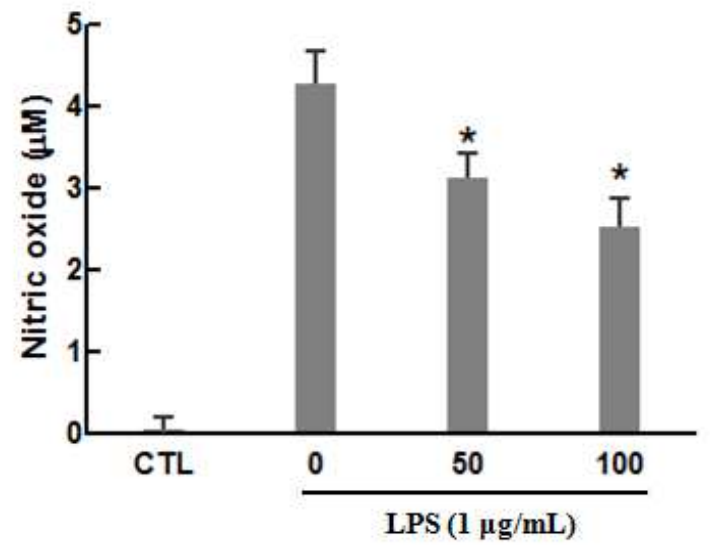

Fig. 3. Inhibitory effect of barley leat ethanol extract on NO production or COX-II and iNOS expression in LPS-stimulated RAW 264.7 cells.

RAW264.7 cells were treated with barley leaf ethanol extracts as indicated dose, then stimulated with LPS (1 $\mu \mathrm{g} / \mathrm{mL})$ for $24 \mathrm{~h}$. NO contents in supernatant was measured suing Griess reagent. Equal amounts of total protein were resolved by SDS-PAGE. Expressions of COX-II and iNOS protein were determined by immunoblot analysis using specific antibodies. The $\beta$-actin was used as a loading control. 

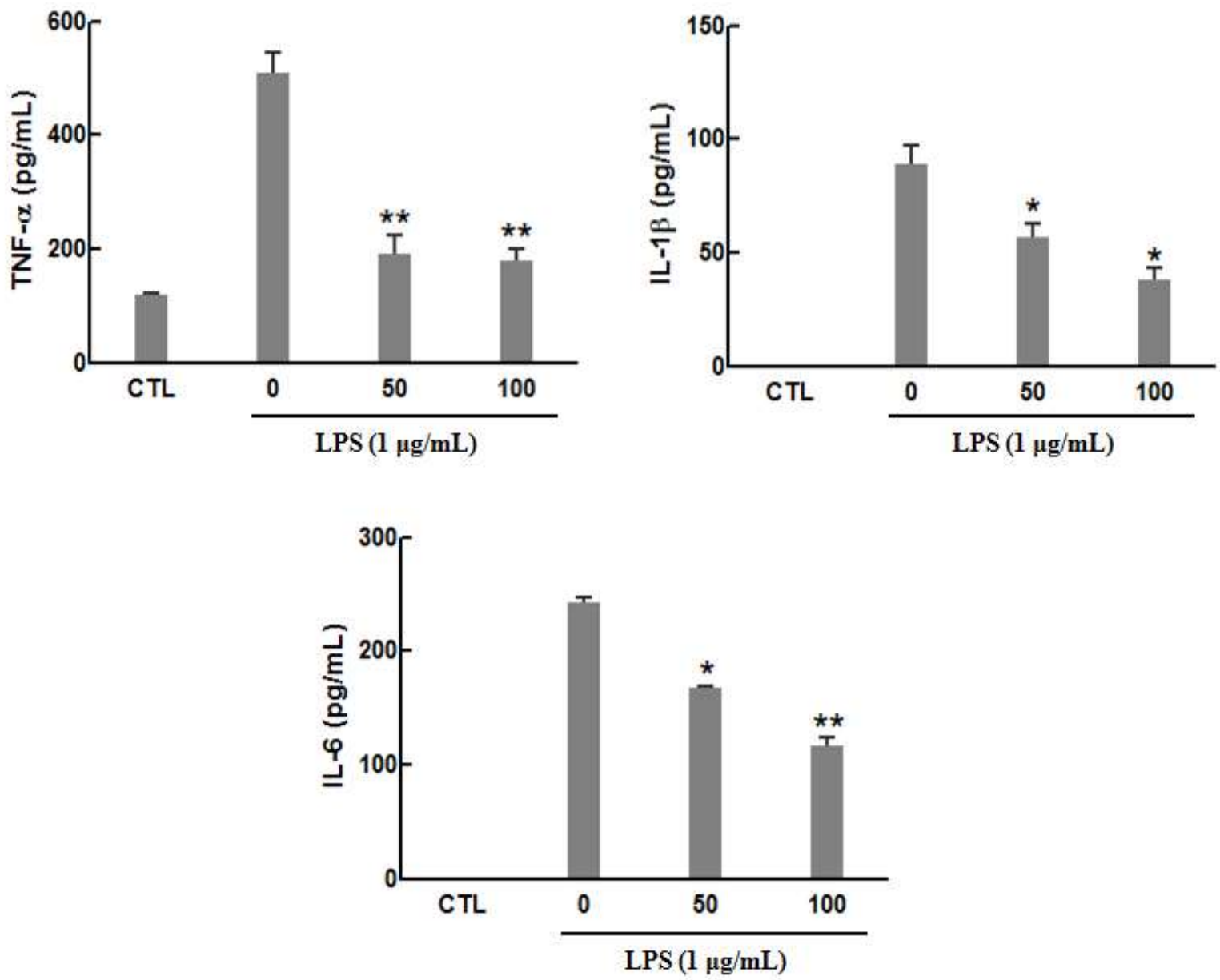

Fig. 4. Effect of barley leaf ethanol extract on LPS-induced cytokine production.

RAW264.7 cells were treated with barley leaf ethanol extracts as indicated dose, then stimulated with LPS (1 $\mu \mathrm{g} / \mathrm{mL})$ for $24 \mathrm{~h}$. The supernants were harvested and TNF-a, IL-1 $\beta$ and IL-6 levels were measured by ELISA as described in Method. The values are means \pm S.D. of three independent experiments. CTL, control. 50, barley leaf ethanol extract $50 \mu \mathrm{g} / \mathrm{mL}$. 100, barley leaf ethanol extract $100 \mu \mathrm{g} / \mathrm{mL}$. *, $\mathrm{p}<0.05 \mathrm{vs}(+) ;{ }^{*}, \mathrm{p}<0.01 \mathrm{vs}(+)$.

\section{보리순 추출물이 MAPKs 발현에 미치는 영향}

MAPK는 염증성 사이토카인 발현에 중요한 조절인자로 서, ERK, JNK, p38 등의 신호전달경로를 가지고 있다. MAPK 분자의 의한 신호 전달 체계는 LPS와 같은 염증 유발 인자에 반응하여 세포를 활성화시켜 염증성 사이토카 인의 발현을 증가시킨다(20). 특히 대식세포에서 LPS는 표면의 toll like receptor 4(TLR4)를 자극하여 하부 세포신호 전달경로인 MAPK의 활성화를 유도하며 활성화된 신호전 달경로는 전염증성 사이토카인, $\mathrm{NO}, \mathrm{PG}$ 와 같은 여러 가지 염증성 매개인자들의 발현을 유도한다(22). 본 연구에서는 보리순 에탄올 추출물의 항염증 효과가 MAPK 분자 조절에 의한 것인지 조사하였다. RAW264.7 대식세포에 보리순 추출물을 처리한 후 LPS로 자극을 주고 세포질에서 단백질 을 분리하여 western blot 방법을 이용하여 각각 분자들의 인산화를 측정하였다. 그 결과 $\mathrm{LPS}$ 에 의해 $\mathrm{EKR}, \mathrm{JNK}, \mathrm{p} 38$ 의 인산화가 증가하였고 보리순 추출물에 의하여 농도의존 적으로 감소되는 것을 확인하였다(Fig. 5).

\section{보리순 추출물이이 NF-kB 활성에 미치는 영향}

염증성 사이토카인의 발현은 NF-kB 전사인자에 의해서 조절된다(23). NF- $k \mathrm{~B}$ 는 외부 자극에 의해 사이토카인, 케모 카인 등 다양한 매개체의 세포 내 합성을 조절하는 전사인 자이다. NF- $\mathrm{NB}$ 는 세포질에서 $\mathrm{I} \kappa \mathrm{B}$ 와 결합하여 불활성화 형 태로 존재하나, IKB가 LPS와 같은 자극원에 의해 인산화가 되면 $\mathrm{I} \kappa \mathrm{B}$ 로부터 유리되어 핵으로 이동하여 iNOS, COX-II 및 염증 사이토카인과 같은 다양한 매개체의 합성을 유도하 게 된다(24). 따라서 LPS로 자극한 RAW264.7 세포를 세포 질과 핵을 분획하여 $\mathrm{NF}-\kappa \mathrm{B}$ 및 $\mathrm{I} \kappa \mathrm{Ba}$ 의 활성화에 대한 보리 순 에탄올 추출물의 억제 효과를 실험하였다. 실험 결과 LPS 자극에 의해 세포질의 $\mathrm{p}-\mathrm{IkBa}$ 의 양은 증가하였고 그와 는 반대로 $\mathrm{I} \kappa \mathrm{Ba}$ 양은 감소하였다. 즉, 인산화에 의해 $\mathrm{IkBa}$ 의 분해가 일어났음을 확인할 수 있었다. 그리고 보리순 에탄 올 추출물 의해 $\mathrm{p}-\mathrm{I} \kappa \mathrm{Ba}$ 의 양이 감소되는 것으로 보아 $\mathrm{I} \kappa \mathrm{Ba}$ 의 인산화가 억제됨을 확인하였다. $\mathrm{I} \kappa \mathrm{Ba}$ 의 분해가 일어나 게 되면 $\mathrm{I} \kappa \mathrm{Ba}$ 와 결합되어 있던 $\mathrm{NF}-\kappa \mathrm{B}$ 가 유리되어 핵 내 
이동이 증가하게 되어 염증 매개체들의 세포 내 합성을 증가시킨다. 이러한 NF-kB 활성은 보리순 에탄올 추출물이 $\mathrm{I} \kappa \mathrm{Ba}$ 의 인산화를 억제시킴으로서 $\mathrm{I} k \mathrm{Ba}$ 와 결합되어 있는 $\mathrm{NF}-\mathrm{kB}$ 의 유리를 억제하여 염증 매개체들의 세포 내 합성을 억제시킨다고 할 수 있다.

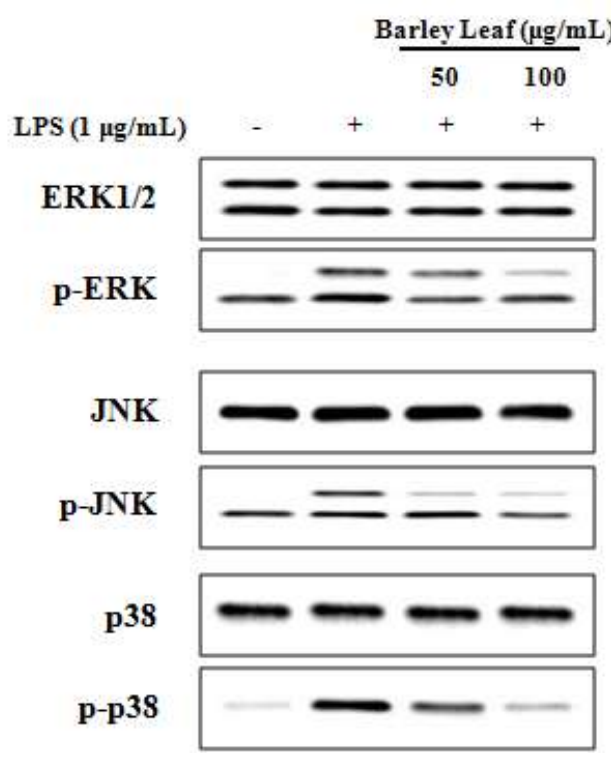

Fig. 5. Effect of barley leaf ethanol extract on MAPK activation in LPS-stimulated RAW264.7 cells.

RAW264.7 cells were treated with barley leaf ethanol extracts as indicated dose, then stimulated with LPS $(1 \mu \mathrm{g} / \mathrm{mL})$ for $24 \mathrm{~h}$. Total proteins were harvested after LPS stimulation. Equal amounts of total protein were resolved by SDS-PAGE. Phosphorylation of ERK, JNK and p38 protein were determined by immunoblot analysis using specific anti-p-ERK, anti-p-JNK and anti-p-p38 antibodies.

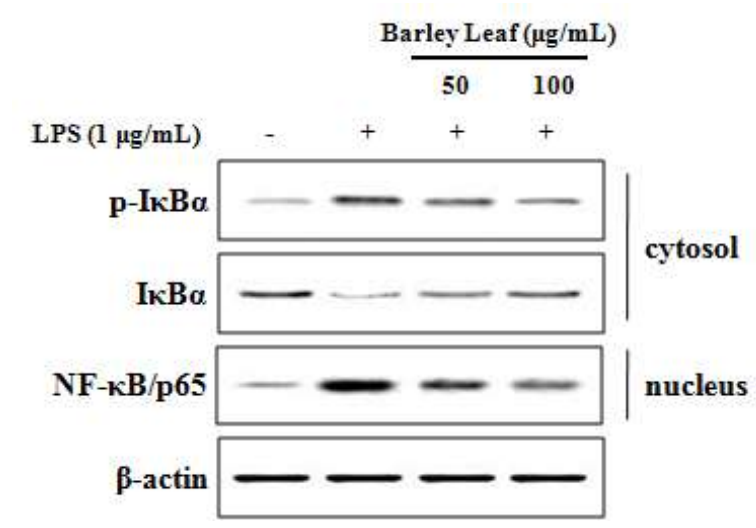

Fig. 6. Inhibitory effect of barley leaf ethanol extracts on the degradation of $\mathrm{I} \kappa \mathrm{Ba}$ and NF- $\mathrm{kB}$ in LPS-stimulated RAW264.7 cells.

RAW 264.7 cells pretreated with a various concentration of barley leaf ethanol extracts for $1 \mathrm{~h}$ and stimulated with $1 \mathrm{\mu g} / \mathrm{ml}$ of LPS. Nuclear and cytoplasmic proteins were isolated by lysis buffer and examined for I $\kappa \mathrm{Ba}$, pI $\kappa \mathrm{Ba}$ and NF- $\kappa \mathrm{B}$ with immunoblot analysis. Equal amount of nuclear and cytoplasmic proteins were analyzed by

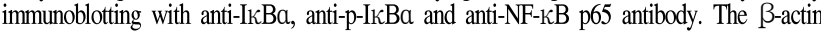
was used as a loading control.

\section{보리순 추출물이 접촉성 피부염에 미치는 영향}

아토피 피부염은 피부장벽기능 이상, $\mathrm{Th} 2$ 사이토카인이 우세한 염증반응, 혈청 $\mathrm{IgE}$ 의 증가를 보이고, 임상 및 면역 학적 소견이 만성 알레르기 접촉피부염과 유사하여 최근에 는 합텐으로 유도한 아토피 피부염 동물 모델을 사용하고 있다(13). Oxazolone 도포로 유도한 아토피 피부염 마우스 모델은 사람의 아토피 피부염과 매우 유사한 임상적, 장벽 학적 및 면역학적 특징을 나타내고 다른 아토피 피부염 모델보다 간단하게 만들 수 있는 모델이다(25). 본 연구에서

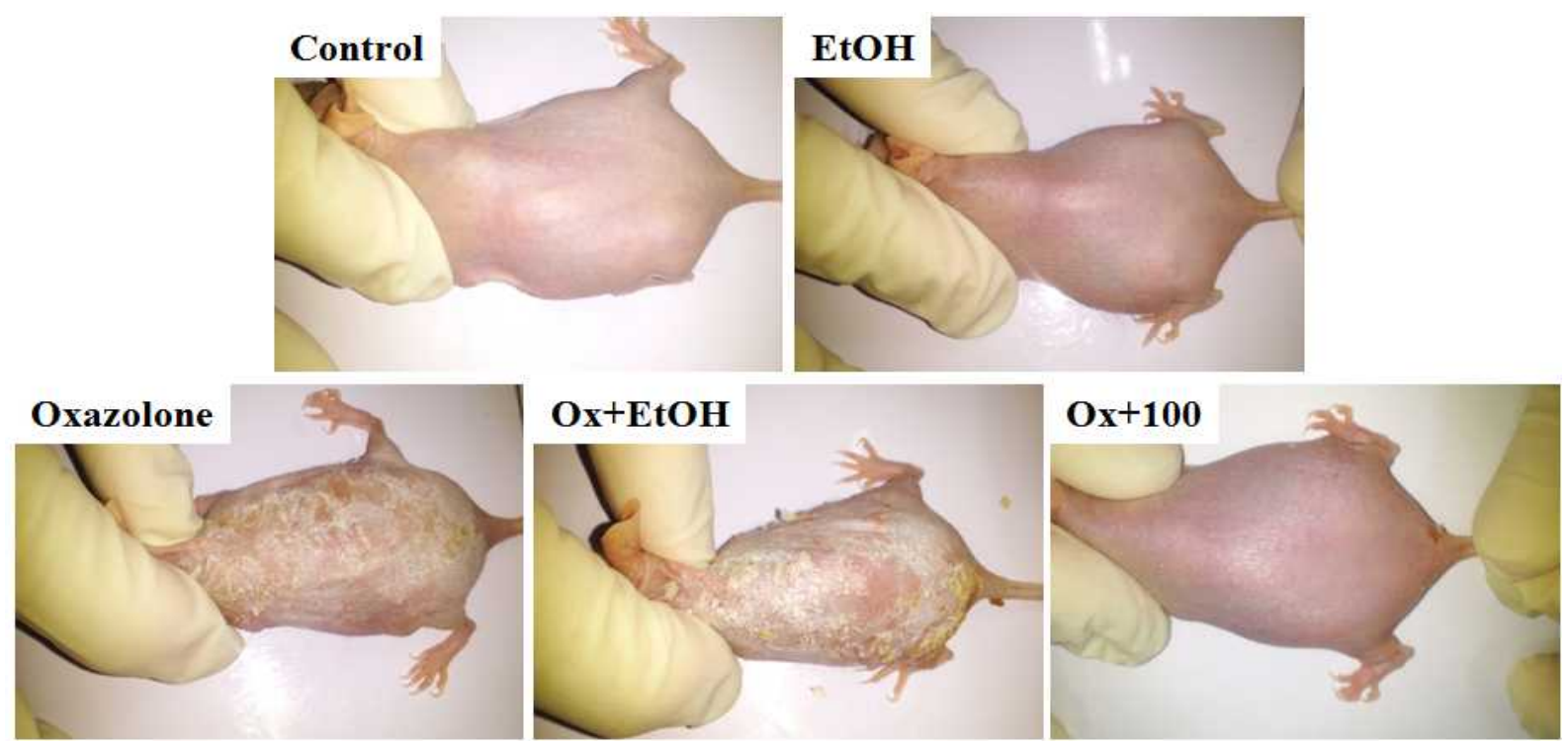

Fig. 7. Effect of barley leaf ethanol extracts on the dorsal phenotypes.

The hairless mice ( $\mathrm{n}=6$ ) were sensitized with $100 \mu \mathrm{l}$ of $5 \%$ oxazolone in ethanol or vehicle (ethanol) applied to the dorsal skin and after 7 days, challenged with $100 \mu \mathrm{l}$ of $5 \%$ oxazolone in ethanol every two days. Barley leaf ethanol extracts $(100 \mu \mathrm{g} / \mathrm{mL})$ were topical administered before oxazolone treatment. After 3 weeks, the difference in the skin irritation between oxazolone group and extracts-treated group was determined based on the change of dorsal pathological phenotype. Control, normal hairless mouse group; $\mathrm{EtOH}$, ethanol-treated group; Oxazolone, oxazolone-treated group; $\mathrm{Ox}+\mathrm{EtOH}$, oxazolone-treated after EtOH group; Ox+100, oxazolone-treated with $100 \mu \mathrm{gg} / \mathrm{mL}$ of barley leaf ethanol extracts group. 
는 oxazolone으로 접촉피부염을 유발한 hairless 마우스 피 부에서 보리순 에탄올 추출물의 항염 효과를 확인하기 위하 여 등에 5\% oxazolone $100 \mu \mathrm{L}$ 로 1 회 감작시킨 후 7일 후에 $5 \% 100 \mu \mathrm{L}$ 를 격일간 9회 도포하였다. 이때 보리순 추출물을 함께 도포하여 접촉성 피부염의 완화 효과를 확인하였다. 대조군으로 에탄올을 같은 방법으로 도포하였다. 마지막 도포 24시간 후 oxazolone 을 도포한 hairless mouse에서 인설, 홍반, 부종, 찰상 등의 습진 병변이 발생하였다. 그러 나 보리순 에탄올 추출물 $100 \mathrm{\mu g} / \mathrm{mL}$ 을 동시에 처리하였을 때 병변 부위가 유의적으로 완화된 것을 육안으로 관찰할 수 있었다. 즉 보리순 추출물이 접촉성 피부염의 완화 효과 가 있을 가능성을 제시하고 있다.

\section{요 약}

다양한 제품들에 사용되고 있는 천연물 소재들의 효능에 대한 체계적이고 과학적인 증거자료와 임상자료는 매우 부족한 실정이다. 이러한 천연물 소재의 과학적 연구는 국 민보건과 건강증진을 위한 다양한 제품개발의 기초자료로 활용할 수 있는 중요한 자료이다. 따라서 본 연구에서는 보리순 추출물을 이용하여 기능성 천연물 소재로서의 가능 성을 검토하였다. 항염증 활성을 조사하기 위해서 대식세 포 RAW264.7에 LPS로 자극시켜 유도된 염증반응에서 보 리순 에탄올 추출물의 매개체 억제 효과를 수행하였고 oxazolone을 이용하여 hairless 마우스에 접촉성 피부염을 유도하여 보리순 추출물의 항염 효과를 확인하였다. 연구 의 결과에서, LPS로 자극한 RAW264.7 세포에서 COX-II, $\mathrm{iNOS}$ 와 같은 염증성 매개체뿐만 아니라 염증성 사이토카 인의 생성 및 발현이 보리순 에탄올 추출물에 의하여 현저 히 억제됨을 확인하였다. 이러한 보리순 에탄올 추출물의 억제효과는 IkB의 분해반응을 억제함으로써 NF-kB의 핵 으로 이동을 억제하여 신호전달체계를 불활성화시키는 것 과 관련이 있는 것으로 나타났다. 또한 보리순 에탄올 추출 물은 NF-kB의 상위 신호전달경로인 MAPKs에도 영향을 미치는 것으로 증명되었다. 대식세포에서의 실험결과를 토 대로 hairless 마우스에 oxazolone으로 접촉성 피부염을 유 발시킨 모델에서 보리순 에탄올 추출물을 처리하여 2 주간 피부 병변을 관찰한 결과 염증반응이 현저히 감소됨을 확인 하였다. 이상의 결과에서 보리순 추출물이 항염증 효능을 가진 천연물 소재로서의 가능성을 제시하고 있다. 기존 연 구에 의하면, 보리 추출물에는 항산화 효과가 뛰어난 폴리 페놀류인 루테오린(luteolin), 사포나린(saponarin) 등이 풍 부하며, 항염증 효과가 우수한 페루릭산(ferulic acid), 루토 나린(utonarin), 그리고 각종 비타민, 미네랄 등이 풍부하다 고 알려져 있다. 또한 superoxide와 hydroxyl 라디칼 생성을 억제할 수 있는 2"-O-glycosylisovitexin이 함유되어 있는
것으로 밝혀졌다. 이러한 성분들에 의하여 보리순 추출물 의 항염 효과가 나타날 것으로 생각된다. 다양한 염증성 질환에서 여러 매개체들의 과도한 발현이 그 질환의 원인임 을 생각해 볼 때 보리순 추출물은 항염증에 관련된 여러 제품들에서 다양하게 활용할 수 있는 천연물 소재가 될 것으로 판단되며 앞으로 보리순 추출물에서 항염 효과를 나타내는 유효화합물의 분리동정 및 생리활성평가에 대한 연구가 진행되어야 할 것으로 사료된다.

\section{References}

1. Jnawali HN, Lee EJ, Jeong KW, Shin A, Heo YS, Kim YM (2014) Anti-inflammatory activity of rhamnetin and a model of its binding to c-Jun NH2-terminal kinase 1 and p38 MAPK. J Nat Prod, 77, 258-263

2. Yun KJ, Kim JY, Kim JB, Lee KW, Jeong SY, Park HJ, Jung HJ, Cho YW, Yun K, Lee KT (2008) Inhibitionof LPS-induced NO and PGE2 production by asiatic acid via NF-kappa B inacti-vation in RAW264.7 macrophages : possible involvement of the IKK and MAPK pathways. Int Immunopharmacol, 8, 431-441

3. Yoon HJ, Moon ME, Park HS, Im SY, Kim YH (2007) Chitosan oligosaccharide (COS) inhibits LPS-induced inflammatory effects in RAW264.7 macrophagecells. Biochem Biophys Res Commun, 358, 954 - 959

4. Li CC, Hsiang CY, Lo HY, Pai FT, Wu SL, Ho TY (2012) Genipin inhibits lipopolysaccharide-induced acute systemic inflammation in mice as evidencedby nuclear factor-kappa B bioluminescent imaging-guided transcriptomic analysis. Food Chem Toxicol, 5, $2978-2986$

5. Xie C, Kang J, Li Z, Schauss AG, Badger TM, Nagarajan $\mathrm{S}$, Wu T, Wu X (2012) The acaiflavonoid velutin is a potent anti-inflammatory agent : blockade of LPS-mediated TNF- $a$ and IL-6 production through inhibiting NF-kappa B activation and MAPK pathway. J Nutr Biochem, 23, 1184-1191

6. Kim MK, Lee IC (2014) Anti-oxidant and anti-inflammatory effects of extracts from blueberry (Vaccinium ashei) leaf. J Korean Soc Beauty Art, 15, 109-120

7. Yoon MY, Han EH, Han YS (2013) A study on anti-oxidant activity and whitening action of Plantago asiatica L. seed extract. J Korean Soc Beauty Art, 14, 259-269

8. You SH, Yoon MY (2013) Effects of anti-oxdiant activity and anti-inflammation action on extracts isolated from A. crenata frui. J Korean Soc Beauty Art, 14, 197-208 
9. Kim YR, Han JS (2014) A study of antimicrobial and anti-oxidative activities on skin inflammation-causing microbes of supercritical green tea extract. J Korean Soc Beauty Art, 14, 71-80

10. Kim DC (2006) Preparation of barley leaf powder tea and its quality characteristics. Korean Soc Food Sci Nutr, 35, 734-737

11. Berridge MV, Tan AS (1993) Characterization of the cellular reduction of 3-(4,5-dimethylthiazol-2-yl)-2,5diphenyltetrazolium bromide (MTT) : subcellular localization, substrate dependence, and involvement of mitochondrial electron transport in MTT reduction. Arch Biochem Biophys, 303, 474-482

12. Ghayor C, Gjoksi B, Siegenthaler B, Weber FE (2015) N-methyl pyrrolidone (NMP) inhibits lipopolysaccharideinduced inflammation by suppressing NF- $\mathrm{kB}$ signaling. Inflamm Res. 64, 527-36

13. Kim JE, Lee YK, Nam SH, Choi SI, Goo JS, Jang MJ, Lee HS, Son HJ, Lee CY, Hwang DY (2010) The symptoms of atopic dermatitis in NC/Nga mice were significantly relieved by the water extract of Liriope platyphylla. Lab Anim Res 26, 377-384

14. Li Y, Wu Q, Deng Y, Lv H, Qiu J, Chi G, Feng H (2015) D(-)-Salicin inhibits the LPS-induced inflammation in RAW264.7 cells and mouse models. Int Immunopharmacol 26, 286-94

15. Deveraux QL, Roy N, Stennicke HR, Van Arsdale T, Zhou Q, Srinivasula SM, Alnemri ES, Salvesen GS, Reed JC (1998) IAPs block apoptotic events induced by caspase-8 and cytochrome $\mathrm{c}$ by direct inhibition of distinct caspases. Embo J, 17, 2215-2223

16. An MS, Kim SH, Yoon HK, Kim WW (2009) COX-2 expression in malignant breast tumors. J Korean Surg Soc, 77, 371-377

17. Jung JY, Lee JR, Byun SH, Jung JW, Kim YH, Kim SC (2010) Inhibitory effect of dioscorea bulbifera $\mathrm{MeOH}$ extract on pro-inflammatory mediator In vitro and In vivo. Korean J Oriental Physiol Pathol, 24, 310-318

18. Choi JY, Lee SY, Cha JH (2009) Expression of iNOS and NADPH-diaphroase reactivity in the lipopolysaccharide treated rat kidney. Korean J Anat, 42, 265 275

19. Kim DH, Hwang EY, Son JH (2013) Anti-inflammatory activity of Carthamus tinctorious seed extracts in RAW264.7 cell. J Life Sci, 23, 55-62

20. Yang H, Oh KH, Yoo YC (2015) Anti-inflammatory effect of hot water extract of aronia fruits in LPS-stimulated RAW 264.7 macrophages. J Korean Soc
Food Sci Nutr, 44, 7-13

21. Park JS, Jung SH (2013) Effects of sandalwood essential oil on the iNOS expression and proinflammatory cytokine production. J Pharm Soc Korea, 57, 70-75

22. Kim BH, Lee YT, Kang KH (2010) Codonopsis lanceolata inhibits inflammation through regulation of MAPK in LPS-stimulated RAW264.7 cells. Korean J Oriental Physiol Pathol, 24, 80-84

23. Kim BW, Kim JI, Kim HR, Byun DS (2014) Antiinflammatory effect of an ethyl acetate fraction from myagropsis yendoi on lipopolysaccharides-stimulated RAW 264.7 Cells. Korean J Fish Aquat Sci, 47, 527-536

24. Chung HJ, Lee HS, Shin JS, Lee SH, Park BM, Youn YS, Lee SK (2010) Modulation of acute and chronic inflammatory processes by a traditional medicine preparation GCSB-5 both in vitro and in vivo animal models. J Ethnopharmacol, 130, 450-459

25. Kim MS, Pyun HB, Hwang JK (2014) Panduratin A, an activator of PPAR- $\alpha / \delta$, suppresses the development of oxazolone-induced atopic dermatitis-like symptoms in hairless mice. Life Sci, 100, 45-54

26. Lu CL, Wei Z, Min W, Hu MM, Chen WL, Xu XJ, Lu CJ (2015) Polysaccharides from Smilax glabra inhibit the pro-inflammatory mediators via ERK1/2 and JNK pathways in LPS-induced RAW264.7 cells. Carbohydr Polym, 20, 428-436

27. Karuppagounder V, Arumugam S, Thandavarayan RA, Pitchaimani V, Sreedhar R, Afrin R, Harima M, Suzuki H, Nomoto M, Miyashita S, Suzuki K, Watanabe K (2014) Resveratrol attenuates HMGB1 signaling and inflammation in house dust mite-induced atopic dermatitis in mice. Int Immunopharmacol, 23, 617-623

28. Lee HS, Kim DH, Hong JE, Lee JY, Kim EJ (2015) Oxyresveratrol suppresses lipopolysaccharide-induced inflammatory responses in murine macrophages. Hum Exp Toxicol, 34, 808-818

29. Kim MS, Jeong JS, Lee HY, Ju YS, Bae GS, Seo SW, Cho IJ, Park SJ, Song HJ (2011) The anti-inflammatory effect of Achyranthes japonica on lipopolysaccharideinduced inflammatory activity in murine macrophages. Korean J Herbology, 26, 51-57

30. Kim YS, Lee SJ, Hwang JW, Kim EH, Park PJ, Jeong JH (2012) Anti-inflammatory effects of extracts from Ligustrum ovalifolium H. leaves on RAW264.7 Macrophages. J Korean Soc Food Sci Nutr, 41, 1205-1210

31. Jeong DH, Kim KBWR, Kim MJ, Kang BK, Bark SW, 
Pak WM, Kim BR, Ahn NK, Choi YU, Ahn DH (2014) Anti-inflammatory effect of ethanol extract from Sargassum fulvellum on iipopolysaccharide induced inflammatory responses in RAW 264.7 cells and mice ears. J Korean Soc Food Sci Nutr, 43, 1158-1165

32. Kim BH, Lee YT, Kang KH (2010) Codonopsis lanceolata inhibits inflammation through regulation of MAPK in LPS-stimulated RAW264.7 cells. Korean J Oriental Physiol Pathol, 24, 80-84

33. Man MQ, Hatano Y, Lee SH, Man M, Chang S, Feingold KR, Leung DY, Holleran W, Uchida Y, Elias PM (2008) Characterization of a hapten-induced, murine model with multiple features of atopic dermatitis : structural, immunologic, and biochemical changes following single versus multiple oxazolone challenges. J Invest Dermatol, $128,79-86$

34. Choi DI, Choi JY, Kim YJ, Lee JB, Kim SO, Shin HT, Lee SC (2015) Ethanol extract of peanut sprout exhibits a potent anti-inflammatory activity in both an oxazoloneinduced contact dermatitis mouse model and compound 48/80-treated HaCaT cells. Ann Dermatol, 27, 142-151

35. Lee HJ, Jung M, Kim JH, Yoon NY, Choi EH (2012) The effect of adipose-derived stem cell-cultured media on oxazolone treated atopic dermatitis-like murine model. Ann Dermatol, 24, 181-188 